\title{
El fascismo español y su sombra en Colombia ${ }^{1}$ Spanish fascism and its shadow in Colombia
}

Ronald Edgardo Cuenca Tovar ${ }^{2}$ Judith Patricia Beltrán Ramírez ${ }^{3}$

\section{Resumen}

El objetivo principal de esta investigación es realizar un estudio histórico, correlacional y descriptivo, entre la violencia bipartidista vivida en Colombia durante la mitad del siglo XX y el fascismo español de la década de los 30 para establecer un nexo causal entre estos dos fenómenos, aclarando que éste no sería el único factor detonante de la violencia bipartidista en Colombia, pero sí uno de ellos, originado en las políticas coloniales y el proceso independentista, hasta llegar a la adopción de la ideología del fascismo español del General Franco en Colombia.

Palabras clave: Fascismo; Dictadura; Democracia; Franquismo; Partidos políticos y violencia.

\begin{abstract}
The main objective of this paper is to carry out a historical, correlational and descriptive study between the bipartisan violence experienced in Colombia during the middle of the 20th century and the Spanish fascism of the 1930s; trying to establish a causal link between these two phenomena, but clarifying that this situation would not be the only trigger of bipartisan violence in Colombia, but one of them, originated in colonial policies and the independence process until the adoption of General Franco's Spanish fascism ideology in Colombia
\end{abstract}

Keywords: Fascism; Dictatorship; Democracy; Francoism; Political parties and violence.

\footnotetext{
${ }^{1}$ Artículo de investigación del Grupo de investigación Derecho' Justicia y Desarrollo global, financiado por la Universidad Manuela Beltrán.

${ }^{2}$ Doctor en Derecho· Docente investigador de la Universidad Manuela Beltrán de Bogotá Miembro del Grupo de investigación Derecho’ Justicia y Desarrollo global. https:/orcid·org/0000-0003-0764-6093 E-mail: ronaldcuencatovar@hotmail.com

${ }^{3}$ Mg. en Derecho constitucional. Miembro del Grupo de investigación Derecho, Justicia y Desarrollo global de la Universidad Manuela Beltrán. https://orcid.org/0000-0002-5832-9509 E-mail: jpbr75@hotmail.com

*Cómo citar este artículo: Cuenca, R., y Beltrán, J. (2018). El fascismo español y su sombra en Colombia. Hojas y Hablas, (16), 113-128. DOI: 10.29151/hojasyhablas.n16a8
} 


\section{Introducción}

AAntes de entrar a hablar de la influencia que tuvieron los ideales fascistas españoles dentro del sistema gubernamental colombiano durante los años 30 y 40, es necesario primero abordar un tema poco tratado, como es la impronta dejada por los españoles durante el periodo colonial en Colombia a través de sus políticas; por ello este artículo partirá desde los tiempos de colonia más precisamente desde la entrada en crisis del sistema colonial en la Nueva Granada, hasta la adopción de ciertas políticas fascistas españolas por parte de movimientos políticos en Colombia durante la década de 1930 a 1940, hecho que influyó en ciertos aspectos de la realidad actual colombiana.

La incorporación de políticas públicas españolas, primero en la Nueva Granada y posteriormente en la República de Colombia no es fortuita, viene de la necesidad de suplir un vacío dejado en el sistema político colombiano desde la caída progresiva del sistema colonial durante siglo XIX. Este será el punto de partida del estudio, que se extenderá hasta la adopción de políticas fascista de tinte español durante el periodo republicano colombiano, y cómo estas contribuyeron a que se presentaran los capítulos de violencia que asediarían a Colombia en los años posteriores y hasta la actualidad.

\section{Metodología}

Enfoque de la investigación: la presente investigación fue desarrollada según el enfoque $\mathrm{Cu}$ alitativo, debido a que en ella se emplearon bases de datos y un estudio netamente bibliográfico, sin incluir ningún tipo de estadísticas o bases de datos de tipo numérico, solo limitándose a aspectos netamente teóricos; Método: dentro de la presente investigación se emplearon diferentes métodos entre ellos, el descriptivo al ser una investigación netamente centrada en la descripción de fenómenos tanto políticos y sociales, también se empleó el método correlacional, al intentar establecer el nexo causal entre dos fenómenos como sería el fascismo español y su influencia en Colombia y finalmente se encuentra el método propositivo, el cual se centra en querer proponer una teoría nueva dentro del campo de conocimiento social y político en Colombia. Las herramientas empleadas dentro de la investigación, fueron libros, periódicos, artículos científicos e informes históricos.

Discusión y resultados

\section{La crisis colonial del siglo XIX y los inicios de la Republica de Colombia}

El fascismo español no sólo fue un producto de un ideal político pasajero, que fue asimilado por Colombia durante los años 30 y 40, sino que, este deseo de asimilación del modelo español por parte del colombiano, fue una constante durante toda la historia colombiana; fenómeno existente desde tiempos de la colonia. Este movimiento asimilatorio, se ve reflejado en los orígenes mismos de la Republica colombiana, ante la necesidad de construir un sistema político y gubernamental nuevo, para afrontar con ello la consecución de la independencia; pero siempre sin separarse por completo del modelo político existente en España.

La crisis colonial empezó con alzamientos populares en la Nueva Granada, que su vez originaron el declive del poder monárquico español durante la invasión francesa de 1808 y al creciente descontento al interior de las colonias con la opresión monárquica, estos dos factores confluyeron y abonaron el terreno para lograr la ruptura definitiva con el gobierno español en 1810.

Aunado a lo anterior, este descontento encontró fundamento en las transformaciones sociales que se presentaron al interior de las colonias, como fue el crecimiento demográfico, la expansión agrícola, el crecimiento minero y la bonanza comercial; transformaciones que impulsaron una mayor intervención política como comercial de la corona española, presión monárquica que se vio reflejada en alza de impuestos y cobros hacia los habitantes de las colonias. Uno de los primeros Neo granadinos en expresar públicamente la inconformidad con la desigualdad entre los habi- 
tantes de las colonias granadinas y la metrópolis, fue Pedro Fermín de Vargas, en su gestión ante el gobierno de Gran Bretaña en 1789, este dijo en esa oportunidad:

La indignación se ha apoderado de nosotros, y nada seamos tanto como sacudir el yugo de una opresión tan odiosa, como la de la corte de Madrid. Es esta opresión demasiado conocida para que no ocupe la atención del gobierno en describirla. El mal ha llegado a su colmo; la población del país es suficiente para aspirar a la independencia, y que el Nuevo Reino de Granada es como un hijo mayor que necesita emanciparse. Las tentativas de 1781 y 1796 lo prueban claramente y este gobierno no está instruida en ellas (Viñas , 1977, p. 10-19).

Ante esta situación, el gobierno español intentó una modernización de las relaciones entre la Corona con sus colonias, pero este intento falló dejando al descubierto la verdadera intención de la Corona, que era, no otorgar ningún tipo de modificación profunda o cambio significativo; sino que su objetivo principal era socavar el poder de los criollos dentro del aparato burocrático y propugnar por el aumento de control sobre las colonias, las cuales solo eran vistas como fuentes de materias primas y de contribuciones. Esta circunstancia propició los frecuentes levantamientos, prueba incuestionable de la tensión que se presentaba entre las elites criollas y las masas populares y el rechazo completo con el sistema colonial.

Es así, como el sistema colonial desconoció todos los derechos y aspiraciones de los mestizos, indios y negros, creando en la élite criolla un temor a perder su hegemonía en manos de las masas populares. Este sentimiento creciente en las clases populares generó un odio y resentimiento hacia el imperio español y en sus representantes en las colonias, por considerar que los gobernantes españoles se encontraban colmados por los vicios, bajas pasiones y por tanto en incapacidad de gober- nar eficiente y justamente (Colmenares, 1989, p. 165 -198).

Esta situación produjo una atmosfera de hostilidad y rechazo hacia todo de origen español, provocando un inminente encuentro violento entre las diferentes etnias que habitaban la Nueva Granada, reflejando así una descomposición socio- racial, entre los gobernantes españoles y las diferentes identidades raciales subordinadas al poder colonial.

\subsection{El intento de control social ejercido por par- te de la corona española}

Los últimos virreyes del Reino de la Nueva Granada se concientizaron de los problemas sociales que sobrevenían en el Reino, como la concentración de las tierras por parte de unas élites y las condiciones deplorables en las que trabajaban las personas del sector rural. Esta circunstancia se refleja en el relato de uno de los campesinos quien manifestaba:

Los hombres medianamente acomodados se llaman aquellos que poseen extensas franjas de tierras adquiridas a viles precios. Estos inmensos terrenos en que por lo regular tenían como feudatarios a los de inferior fortuna. Los primeros preservaran más arraigados a sus posesiones por la ganancia que reciben de sus esparcidos domésticos; pero estos, que forman el mayor número de habitantes libres, hacen propiamente una población vaga y volante que obligados de la tiranía de los propietarios, transmigran con la facilidad que se conceden el poco peso de sus muebles, la corta perdida de su rancho y el ningún amor a la pila en que fueron bautizados (Posada Eduardo y Pedro, 1910, p. 238).

La solución dada a esta problemática por parte de los gobernantes españoles, no fue asegurar el acceso a la tierra a las personas menos favorecidas, o asegurar una equitativa distribución de la tierra evitando la monopolización de la propiedad. En cambio, la tan esperada reforma solo se 
limitó a recoger a los desamparados y mendigos $y$ ubicarlos en poblados determinados; pero no analizó el problema social de fondo ni intento disminuir la pobreza a través de una reforma agraria.

Estas medidas poco efectivas para la sociedad más empobrecida no afectaron los derechos de los hacendados, garantizando así que los grandes terratenientes no se alzaran en contra de la corona, sacrificando a los desamparados y al pueblo más humilde el cual se encontraba en pobreza, obligándola a colonizar nuevas tierras de esta manera salvaguardando el poder de los terratenientes, ejerciendo un control social con fundamento en la pobreza y el desarraigo poblacional.

Otro mecanismo de control social implementado por la Corona fue el intento de reavivar el derecho natural de origen romano-cristiano-español centrado en la elección divina de los gobernantes apoyados en la religión católica como mecanismo de control social, con la cual se intentaba justificar la renuencia a un cambio atacando las nuevas realidades sociales, como fueron las revueltas de esclavos, y el intento de legitimar la esclavitud; esto en palabras de un orador franciscano:

Todo poder viene de lo alto del Supremo Monarca de los cielos que ha confiado al de la tierra una porción de su soberana autoridad; y que por lo tanto resistir a él, o sus ministros entre los cuales uno es, como la cabeza del monarca, que juzga; otro como el brazo, que pelea; y otro como los ojos que velan; resistir digo a esto es ir contra todo espíritu de la religión católica y contra el orden de la divina providencia (Raimundo, 1782, p. 23-24).

Fueron importantes pero infructuosos todos los intentos realizados por parte de la monarquía para encontrar su legitimación tanto de su título y sus leyes en un origen divino y en una mitología alrededor de estas figuras. Esta mitifi- cación de un origen divino se presentó dentro de los motines suramericanos del siglo XVIII en los cuales las masas gritaban espontáneamente (Vilar, 1982, p.21) "viva el Rey y muera el mal gobierno", frase que también se utilizaba ampliamente en Europa. A pesar de esta mitificación de los origines del poder, el ansia de libertad superó estos pensamientos y tradiciones originando un sentido independentista.

\subsection{La crisis del orden socio - racial}

Esta crisis se presenta en la descomposición del orden socio-racial basado en las discriminaciones raciales; esta crisis se debió al crecimiento del mestizaje y la atenuación de las diferencias raciales, por estos motivos se tornó imposible seguir basando un sistema social en políticas discriminatorias, en las cuales unas razas eran superiores a otras. Esto se evidencia en las cifras las que revelan, que para 1778 la población del Nuevo Reino ascendía a 891.077 habitantes; 290.599 blancos, 391.869 mestizos, 151.758 indígenas y 57.077 esclavos (Aguilera y Vega, 1998, p. 70- 71).

La elevada población de mestizos trajo consigo importantes cambios al interior de la sociedad, debido a que empezaron a ser titulares de importantes extensiones de tierra, también se incorporación como trabajador al desarrollo de las haciendas y convirtiendo se en arrendatarios de las reservas territoriales que usufructuaban los indígenas. El crecimiento del mestizaje también se extendió a temas laborales y educacionales. Debido a que inicialmente las personas de ascendencia europea eran los únicos que tenían prioridad en el acceso de los empleos dentro de la administración pública, igualmente al momento de ingresar a las universidades, los colegios y los seminarios. Pero en la medida en que los mestizos obtenían cada vez más poder económico y amasaban importantes fortunas este hecho sentenció la terminación de la organización social basada en el linaje; esto se vio reflejado en diferentes levantamientos, deserciones y homicidios cometidos por los esclavos en contra de sus amos, estas circunstancias paula- 
tinamente presionaron para que ocurrieran cambios sociales, como asegurar derechos mínimos tanto de esclavos como de mestizos, tales como la protección, alimentación, educación, la práctica de una religión y asegurar su amparado durante la vejez o enfermedad.

Los anteriores hechos fueron ideales para el surgimiento de las ideas de la revolución francesa durante la ocupación de España por los franceses entre 1808 y 1814 ; en las colonias este periodo de ocupación francesa de España trajo consigo la confusión a todo nivel gubernamental especialmente sobre que órgano gobernaría en representación de la nobleza española ahora en posición de destierro. Esta situación generó un vacío de poder, el cual fue suplido por movimientos republicanos, los cuales propugnaban los ideales revolucionarios de tinte francés que son tan conocidos como: la libertad, la igualdad y la fraternidad para todos los habitantes de la Nueva Granada, lo que concluyó a la larga con la Independencia de estos territorios. Este pensamiento iba en contra de los supuestos derechos inmemoriales alegados por España sobre las tierras de sus colonias, sus habitantes y sus creencias las que se basaban principalmente en el catolicismo, la decadencia de esta creencia condujo al surgimiento de las ideas de liberación colonial, la proclamación de los derechos del hombre y del ciudadano, la tesis de la soberanía popular y la búsqueda de la identidad socio-territorial. Dichas ideas tuvieron su mejor receptor en las clases medias y bajas de los territorios ocupados, sitios propicios en los cuales estas clases trabajadoras no ejercieron la suficiente presión sobre las clases élites las que continuaron apoyando y respaldando al orden social monárquico establecido tal y como se presentó en Haití (Cordoba, 1967, p.211).

\section{Surgimiento del liberalismo en Colombia como movimiento político y popular}

El surgimiento de la Republica de Nueva Granada la que posteriormente sería la Republica de Colombia, propulsora de diferentes partidos políticos entre ellos el liberalismo que se funda- menta en los ideales de la revolución francesa acompañado de un espíritu modernizador tanto en aspectos sociales, políticos y económicos.

Los ideales presentes entre 1847 y 1863 a la par de la presencia de unas políticas modernas, permitirían la integración entre los habitantes de este territorio mediante la participación de políticos jóvenes que llegarían a dar un nuevo aire a una estructura política en decadencia.

Esta situación dio origen a enfrentamientos partidistas entre los partidos de élite o de burguesía, los cuales eran remanentes del antiguo régimen monárquico apoyado por la Iglesia Católica y estos nuevos movimientos políticos (Aguilera y Vega, 1998).

Durante este tiempo de ascenso del liberalismo se presentó el fenómeno que consistía en que la política ya no se encontraba limitada a las élites o burgueses, sino que por el contrario se hizo extensiva a todos los ciudadanos desde la clase media hasta las clases menos favorecidas a través de agrupaciones populares, abriendo así un espacio de expansión a teorías políticas de diferentes tintes asimilando tanto políticas populistas como demagógicas.

Aquí se empieza a observar dentro de las clases media y baja la aparición de conceptos como pueblo, soberanía popular, libertad, igualdad y fraternidad, a la vez que la aparece la crítica activa en contra de las élites burguesas, con el fin de realizar el ideal republicano. Y se presentó un nuevo ideal de avance social a través de la educación, entendida no sólo como un derecho sino como la expresión de igualdad entre las diferentes clases sociales.

Es así como el desarrollo de estos nuevos ideales liberales inicialmente en la Republica Neo Granadina y luego en la República de Colombia, no fue pacífica sino que por el contrario encontraron una serie de obstáculos, como por ejemplo; 
que este territorio a principios del Siglo XIX era preminentemente agrario, no existía industria, la economía se fundamentaba todavía en la explotación del oro, se encontraba frente al reto de reconstruir la economía luego de la guerra civil, instituir un sistema legal y administrativo, y el sostenimiento de unas fuerzas armadas. Para solucionar estas problemáticas se empezaron a conceder incentivos para la creación de empresas, como fábricas de loza, papel, vidrio, tejidos, paños, sombreros y ferrerías, para lo cual se les concedió préstamos exentos de impuestos de mano de obra y materias primas (Tovar Pinzon, 1996), se incrementaron las exportaciones de tabaco, quinua y sombreros, hechos que significaron una lenta activación de la economía. Esta relativa bonanza fue interrumpida por la crisis comprendida entre 1876 y 1877 , la cual estuvo ligada a una guerra civil, entre 1893 y 1898 . Luego de esta guerra civil se presentó una nueva bonanza se vio representada por el café; la producción de café en este tiempo fue difícil debido a los problemas de transporte, situación que se agravó más tarde con el estallido de la guerra de los mil días en la última década del siglo XIX (Ocampo, 1985).

A pesar de la intención por parte del Partido Liberal de implementar ampliamente reformas tanto económicas como sociales, estas no se llevaron hasta su concretización plena, como lo fue la implementación de un modelo libre cambista. Estas reformas no solo encontraron una resistencia por parte de la burguesía, sino que también encontraron una resistencia en las mismas condiciones de infraestructura del país como el pésimo estado de las vías de comunicación, lo apartado de los pueblos lo cual hacia muy costoso su transporte, la baja inversión extrajera y un escaso movimiento de los capitales. Este proceso de segmentación económica dio origen a los Estados Unidos de Colombia (1863-1865), el cual era un sistema político que otorgaba soberanía a cada uno de los estados miembros contando con neutralidad del gobierno central, pero con diferentes regímenes políticos, constitucionales y legales.
Con el fin de interconectar el país y mejorar las condiciones de producción y exportación de los Estados Unidos de Colombia, en la década de 1870 se inició el proyecto de construcción del ferrocarril del norte, cuyo objetivo era unir a la ciudad de Bogotá y los departamentos de Boyacá y Santander con el rio Magdalena.

La obra generó el descontento del departamento del Cauca y la región de la Costa Atlántica que veían que su realización obedecía a intereses localistas, lo cual contribuyó al debilitamiento político del régimen federal y al aplazamiento de los trabajos del ferrocarril. Esta fricción entre estados significó la disolución de los Estados Unidos de Colombia, retornando así de nuevo al modelo centralista unitario; además de lo anterior se presentaron las pugnas en el interior de los estados, la fragmentación de las nuevas oligarquías económicas y el enfrentamiento de los intereses económicos regionales.

\section{Lucha partidista}

La lucha entre los dos partidos tradicionales de Colombia, el Partido Liberal (Popular) y el Partido Conservador (Burgués), y los pocos avances en el aspecto económico se originaron en el consenso entre estos dos partidos por el proceso de liberación de la economía iniciado por el Gobierno del General Mosquera (1845-1849) en su época de conservador reformista. Las tensiones entre los dos partidos fueron creciendo con el tiempo y con la unión entre el partido conservador y el clero, los cuales patrocinaban el control y la estandarización de una sola creencia contraria al pensamiento liberal. El problema se incrementó cuando el gobierno conservador se subordinó a este último y lo convirtió en un aliado educativo orientado para los fines del Gobierno.

Durante los periodos de gobernanza de los presidentes de orientación liberal se toman medidas que afectaron al gran aliado del Partido conservador que era la Iglesia católica, una de las medidas más controvertidas adoptadas por el go- 
bierno liberal fue el destierro del Arzobispo Mosquera, la expulsión de los Jesuitas, la separación de la Iglesia del Estado y la reforma del patronato. Situación que desencadenó el disgusto generalizado de los adeptos del Partido Conservador y la Iglesia, convirtiendo estos dos actores tanto políticos como sociales en grandes aliados en la lucha en contra del liberalismo, convirtiendo al Partido Conservador como el gran defensor de la Iglesia, las tradiciones y las costumbres.

En cambio, durante los periodos de gobernanza de presidentes de orientación conservadora, se intentó de dividir la población entre burguesía y pueblo, es por ello que en este periodo histórico el término "Pueblo" dejo de ser una abstracción y adquirió la corporalidad de "el Vulgo" (Ortiz, 1972, p.32), "aquellos que vestían ruana y caminaban descalzos" y los "artesanos".

En este periodo el artesano se convirtió en el principal interlocutor entre el gobierno y las clases menos favorecidas debido a que esta cofradía se mantuvo organizada y continuó exigiendo un trato igualitario entre las diferentes clases sociales. Por ello el término "Pueblo" se empezó a usar de manera despectiva en aquellas zonas donde las jerarquías socio económico y racial eran todavía muy marcadas.

Es así como el movimiento político denominado "conservatismo" trató de neutralizar la acción política de las sociedades democráticas en aras de defender el clero en nombre de la "la religión santa de Jesucristo" (de Cuervo, 1946) (Tomo II, p. 124). Esta disputa se presentó más clara con el enfrentamiento entre el clero y los liberales se evidenció, por ejemplo, durante la gobernación de Ramón Mercado (1849-1853) cuando fueron sustituidos los nombres de los curatos de Cali "La mayoría de patrones religiosos, por libertad, igualdad, fraternidad y Democracia" (Castro, 1990, p. 68).

Otro mecanismo de neutralización utilizado por el conservatismo fue el de rechazar las ideas que atentaran contra la propiedad o el orden socio-económico del territorio, la lucha en contra de los movimientos comunistas y socialistas, tal y como se ve en la creación de la sociedad de Amigos de la Orden de Buga, donde, uno de sus principales objetivos era "Combatir las principales atrocidades del comunismo, de la inmoralidad y de la impiedad en materia de religión" (Periódico el Día, 1850).

El Partido Conservador consideraba que los ideales promulgados por el Partido Liberal de libertad, igualdad y fraternidad, instigarían el desorden y la anarquía, lo que produciría la persecución de la Iglesia y los que no compartieran el ideal político liberal; por ello dentro de ciertas clases privilegiadas se percibía con temor la idea de igualdad absoluta, porque consideraban que existía una desigualdad natural imposible de saldar, así que el concepto igualdad era concebido por los miembros del Partido conservador como:

La igualdad de los derechos y de los deberes, de la igualdad fundada en el origen de los hombres por haber sido creados por el mismo padre. Los que proclaman la igualdad absoluta mienten; los que predican al pueblo esa clase de igualdad quimérica lo alucinan, lo toman de escalón para subir a los altos puestos y luego lo tiranizan. Es preciso que exista igualdad pero que la propiedad se respete (Periódico el Día, 1850).

Estas tensiones ocasionadas por las reformas políticas y la retórica conservadora generaron el primer enfrentamiento partidista la noche del 15 de enero de 1845 , durante una reunión de la sociedad creada por los conservadores, la cual fue invadida por los democráticos con gritos, insultos y disparos de trabuco. Entre 1848 y 1851 se presentó un incremento de la lucha partidista en las provincias de Buenaventura y Cauca. En estas zonas miembros del partido liberal incendiaron casas, asaltaron, destruyeron cercas y plantaciones de propiedad de miembros del Partido Conservador, es claro que estos actos violentos no fueron 
fortuitos sino que fueron incubándose en la sociedad colombiana como una reacción a la desigualdad entre las clases sociales, el acaparamiento de tierras y la explotación desmedida por parte de los grandes hacendados a la población campesina ante lo cual no existía ningún esfuerzo gubernamental por solventar esta situación.

\section{La regeneración conservadora}

El período conocido como la regeneración conservadora (1886 - 1903) se basó en el ascenso del partido conservador al poder, lo cual trajo como consecuencia la abolición de los pocos logros alcanzados por el partido liberal en el marco de la Constitución de 1886, mediante la imposición del antiguo orden social basándose en principios católicos y moralistas, con el objetivo de luchar en contra de la anarquía y el populismo originados en ideales de la revolución francesa. Estos objetivos se desarrollaron durante la Republica Conservadora (1903 - 1930) con la característica principal de la limitación de los principios democráticos en Colombia y la implementación de un rígido control social de la población, lo que generó levantamientos populares como lo fueron el motín de 1893 y la conspiración de 1894 . De esta manera el Partido Conservador impuso un orden social de exclusión de los oponentes políticos y el exterminio de todo lo que pudiera representar un levantamiento popular o movimiento social distinto al promulgado por ellos. Cualquier tipo de manifestación contraria al pensamiento conservador era considerado como doctrinas liberales, ateas, masónicas, socialistas, anarquistas y comunistas.

Dentro del ideal conservador no se propugnaban ideas anticapitalistas, sino que apoyaba el retorno de las tradiciones católicas y modelos sociales coloniales, claramente diferenciados en clases, con el fin de impedir la lucha entre estas últimas. Lo anterior constituyó un modelo estático y pétreo de una idea utópica alejada de la realidad social colombiana.
El mayor representante de esta ideología fue Miguel Antonio Caro, sin embargo, este pensamiento se impuso a nivel constitucional y social; Caro consideraba que los radicales habían causado grandes perjuicios a la sociedad colombiana al desconocer la moral católica del pueblo colombiano y observó la necesidad de restablecer los valores cristianos para rectificar el destino de la nación. Consideraba que Colombia había llegado a este punto debido a "la demagogia francesa de 1848" la cual había influido "en la juventud ilusa que terminó dando en tierra con las instituciones". (Uribe, 1986, p. 34).

Durante este período todos los avances conseguidos por el Gobierno liberal, como el reconocimiento de los derechos individuales, la creación de los jurados de conciencia, la promoción de las libertades de prensa y opinión, los debates generados alrededor de temas complejos como la democracia política, la apreciación del ciudadano como el producto de la revolución francesa, la cual exaltaba la responsabilidad individual de la personas como base para fundar la sociedad política, éstos fueron abolidos por el conservatismo por considerarlos contrarios a la Iglesia y a la formación de un aparato estatal fuerte, lo que para su consideración amenazaba la existencia propia del Estado; es así como bajo los ideales conservadores se empieza a sustituir trilogía de libertad, igualdad y fraternidad por la caridad, obediencia y cristiandad, lo cual se orientaba a forjar no a un ciudadano sino a un buen Cristiano (Urrego, 1990), esta ideología le otorgó un poder desmesurado a la Iglesia católica la cual inculcó una intolerancia ante cualquier pensamiento que la contrariara, con fundamento en esto la Iglesia encontró vía libre a la persecución contra todo aquello que consideraba manifestación del mal sin importar si estaba justificada o no, lo que significó la inmersión de Colombia en una especie de oscurantismo propio de la edad media.

Ante estas políticas las personas menos favorecidas decidieron rebelarse en contra del siste- 
ma implementado, como lo fue el motín de 1883, la conspiración artesanal de 1894 y la guerra civil de 1895, lo cual demuestra que los ideales políticos de la revolución francesa seguían con vida.

Una de las consecuencias más terribles de esa política fue la guerra conocida como de los mil días (1899 a 1902), originada en las diferencias entre conservadores y liberales por el manejo que se le estaba dando al país, el fortalecimiento de la facción guerrerista liberal y el vacío de poder ocasionado por la muerte del Rafael Núñez. El levantamiento tuvo su epicentro en Bogotá, pero fue extendiéndose a otros sitios de Colombia. Estaba dirigido por Juan Félix León (Abogado y profesor de derecho), Liborio de Cantillo (Abogado), Eustaquio de la Torre Narváez (Hacendado Cafetero), Rafael Uribe Uribe (Abogado y socio del anterior), el General Santos Acosta (Ex presidente), Tomas E Abelló (Comerciante) y Manuel Muñoz (Negociante) (Nieto, 1985).

El objetivo principal de los primeros momentos de la revuelta era tomar varias fortificaciones militares en Bogotá, pero el alzamiento falló en este cometido inicial por el pronto actuar de la Policía y el Ejército que los detuvieron en los primeros momentos de la revuelta. Pero a pesar de esto el 23 de enero de 1895 se declaró la guerra en varios lugares del país, como en los departamentos de Boyacá, Cundinamarca, Santander y Tolima, en los cuales el ejército al mando de líderes conservadores venció a los amotinados liberales. Pero esta guerra civil no fue la única situación de guerra civil que se presentaría en Colombia, porque la violencia se volvería a presentar más adelante como el período de la violencia bipartidista (1946 a 1966), la cual causó miles de muertos y un desangramiento sistemático de Colombia.

\section{Fascismo en Colombia y su relación con Es- paña}

En Colombia existió una figura particular de Fascismo que se presentó no en una imagen de dictador de origen castrense o caudillo popular; sino en la sucesión en varios Presidentes aparentemente elegidos democráticamente pero con una constante que es la pertenencia de todos ellos al Partido Conservador siguiendo una misma política de represión y persecución de partidos opositores, prueba de ello son Mariano Ospina Pérez y Laureano Gómez, los cuales se sucedían en el poder por espacio de cuatro años. A pesar de que esta práctica ya se había extendido en el tiempo, estos dos presidentes fueron los más emblemáticos por el grado de violencia desplegado, las cuales se consideran dictaduras constitucionales (López y Restrepo, 1986, p. 18-19).

Estos insólitos presidentes dictadores aparecen dentro de la historia de Colombia no como dictadores sino como presidentes de la República, pero siempre mostrando ideales propios del Fascismo español, debido a que compartían el mismo eje ideológico de Familia, Patria y religión, incluso mostrando similitudes al momento de implementar políticas restrictivas de la libertad de asociación y de expresión, y la lucha en contra de los partidos opositores, políticas que se extendieron hasta el golpe de estado propiciado por el General Rojas Pinilla, lo que dio fin a la época de la violencia.

La influencia del régimen del General Francisco Franco no sólo afectó a Colombia sino también a otros países Latinoamericanos. La exportación de la ideología Fascista Español fue una medida que adoptó el Franquismo para no quedar completamente aislado de la comunidad internacional debido al bloqueo impuesto por la ONU al régimen franquista por ser considerado fascista; esta ideología fue aceptada en países como Colombia debido a las grandes similitudes tanto culturales, lingüísticas, religiosas y sociales existentes en ambos países, lo que convertía a países como Colombia, en el campo perfecto en donde se podía exportar la ideología del Franquismo (Delgado, 1988, p. 45-48).

Una vez terminada la época de la violencia bipartidista, la cual estuvo marcada por políticas 
fascistas de tinte español, aparece otra fase histórica marcada por los ideales fascistas en Colombia, que se puede ver en la ciudad de Sitges que conmemora el bipartidista y excluyente pacto, que el máximo representante del franquismo colombiano, el ex presidente Laureano Gómez, redactó y suscribió en 1957, con el jefe del liberalismo, el liberal de derecha Alberto Lleras. Acuerdo que, sumado a la declaración de Benidorm de 1956, constituyó el presupuesto básico del texto constitucional plebiscitado en 1957. Norma suprema que sirvió de célebre sostén, durante casi toda la segunda mitad del siglo pasado, a ese antidemocrático y anti pluralista régimen político conocido con el nombre de "Frente Nacional" y que constituyó, por absurdo que parezca, la positivización constitucional del franquismo colombiano (Calle, 2009).

Este acuerdo que paradójicamente cesó la lucha entre los Partidos Políticos Liberales y Conservadores, pero que sesgó la posibilidad de elección libre en Colombia, debido a que limitó la posibilidad de elección de los colombianos al prohibir escoger representantes del partido que desearan en el momento que quieran, imponiendo la elección entre un candidato entre los dos partidos, continuando siempre con la misma ideología política de los dos partidos políticos sin posibilidad de cambios.

Los ideales propios del fascismo no se desarrollaron de manera abierta y tangible en este periodo, sino que se desarrolló bajo la fachada de una democracia, cuando a todas luces era evidente que ésta no existía porque era un pacto cerrado y excluyente. Este modelo surgió bajo una confluencia histórica como la segunda guerra mundial, el ascenso de los Estados Unidos como potencia global y el temor generalizado por el ascenso del comunismo y su difusión a nivel internacional, hechos que potenciaron movimientos nacionalistas basados en un temor al comunismo y a la lucha entre clases.
El "Frente Nacional" fue el acuerdo que siguió al Gobierno del General Rojas Pinilla, este acuerdo fue una coalición política y electoral colombiana entre liberales y conservadores vigente entre 1958 y 1974.

La principal característica de este período fue el acuerdo de igualdad entre los dos partidos políticos durante 16 años en los cuales se planteaba que éstos se alternaran la presidencia de la República durante 4 años, periodo en el cual los dos partidos políticos tendrían una idéntica cantidad de parlamentarios liberales y conservadores en el Congreso. Este movimiento se originó a partir de la entrega voluntaria de poder del General Gustavo Rojas Pinilla quien lo ostentaba desde el golpe de Estado de 1953 a una junta militar constituida entre 1957 y 1958.

El gobierno del General Rojas Pinilla no se puede considerar como una dictadura desde el concepto propio de dictador, porque el golpe de Estado tuvo como objetivo principal detener la confrontación bipartidista entre el partido liberal y el partido conservador, la cual estaba destruyendo el país y sumergiéndolo en una violencia generalizada. Esta decisión fue legitimada en el clamor popular por detener el derramamiento de sangre. Así, el General Rojas Pinilla inició un amplio plan de entrega de los bienes hurtados a la población campesina durante la guerra, lo cual, desde mi punto de vista, puede ser considerado una democracia tácita, dado que fue un gobierno impuesto y respaldado por el pueblo.

El gobierno de facto del General Gustavo Rojas Pinilla fue la consecuencia de las acciones de dos personajes claves: Mariano Ospina y Laureano Gómez, como máximos líderes del Partido Conservador y los más destacados representantes de la ideología franquista, causantes del desencadenamiento de la guerra civil colombiana conocida como la violencia, la cual tiene gran similitud con la Guerra Civil Española. También se puede observar durante este período una conexión entre el 
partido conservador y la Iglesia católica en contra de la modernización del Estado y del derecho, que intentó adelantar el partido liberal en los años treinta durante su gobierno.

La guerra bipartita colombiana a diferencia de la guerra civil española no empezó con un ataque frontal a la legalidad mediante el uso de las armas, sino que, se presentó como una persecución a la oposición política cohonestada o justificada por el gobierno del partido conservador, el cual había sido elegido de manera popular. En Colombia nunca fue declarada oficialmente la guerra civil por parte de las dictaduras civiles, pero sí se aplicaron los principios rectores propios del régimen franquista: el nacional catolicismo y la represión del comunismo, el judaísmo y la masonería (Calle, 2009).

La relación entre España y Colombia se pone de manifiesto en los años treinta, cuando en España había caído la monarquía para dar paso a la II Republica (1931 - 1936) y en Colombia había finalizado la hegemonía conservadora (18861930) con el triunfo electoral del partido liberal y la instauración de la república liberal (1930-1945) en alusión expresa de la II República española, impulsada por la derrota de los terratenientes el clero, el ejército y los adelantos realizados por la II República española. Estas reformas fundadas en la II Republica fueron incluidas dentro de la reforma constitucional colombiana de 1936 (Tirado, 1981, p. 343-356) reformas que fueron impulsadas por el presidente de la República Alfonso López Pumarejo, lo que a la larga fue la génesis del periodo de la violencia en Colombia.

Uno de los cambios más importantes se realizó en la justicia, cuando el presidente Pumarejo en uso de sus facultades extraordinarias cambió por completo la Corte Suprema de Justicia e impuso en ella magistrados más afines a las nuevas corrientes teóricas del derecho. A partir de 1935, se propuso que la Corte Suprema de Justicia de Colombia actualizara los conceptos y métodos del
Derecho, y realizara cambios en el derecho privado para que se armonizaran con los cambios constitucionales en materia de derecho a la propiedad. El senado de Colombia se ocupó también de varias reformas constitucionales, a saber: declaró que la propiedad era susceptible de enajenación forzosa mediante indemnización equitativa y autorizó la intervención estatal en la industria y empresa, con el fin de racionalizar la producción, distribución y consumo de la riqueza o de dar protección al trabajo (López, 2004, p. 327-328).

Una de las más claras alusiones del pensamiento Republicano en la legislación colombiana, fue la de introducir la noción que la propiedad, la cual cumplía una "función social que implica obligaciones". De esta manera se toma la tesis del jurista francés León Duguit, que dio fruto a estas primeras concepciones, como lo fue la realización de una reforma agraria, tal y como ocurrió en España. También en Colombia al igual que en España se pretendió separar el Estado de la Iglesia y edificar el nuevo modelo de Estado bajo las bases de un Gobierno laico sin ningún tipo de afinidad con religión alguna. Así se suprimió la invocación a Dios del preámbulo de la Constitución de 1886, se garantizó la libertad de conciencia, la libre enseñanza y además se eliminó el artículo que declaraba expresamente la religión católica como religión de la nación.

Ante estas reformas tanto los miembros del partido conservador y la Iglesia católica se manifestaron en contra de dichas modificaciones, como se observa en el manifiesto episcopal del 17 de marzo de 1935:

si llegare al fin a aprobarse la Constitución proyectada, verán nuestros legisladores que no impunemente se violentan las conciencias en lo que tiene de más caro, que es la fe de sus antepasados (...) Esta declaración implica una prevención terminante al congreso de que todo el pueblo colombiano está con nosotros cuando se trata de la defensa de la 
religión y que llegado el momento de hacer prevalecer la justicia ni nosotros ni nuestro clero, ni nuestros fieles permaneceremos inermes y pasivos". (Mercado, 2015)

Es así como se presentó una declaratoria de guerra en el aspecto ideológico entre el clero y el estado liberal, apoyado por los conservadores lo que desencadenaría en los años 40 el enfrentamiento armado. Con el inicio de la guerra civil española, Laureano Gómez principal representante de la ideología fascista española, fundado en esta ideología arremete en contra del presidente Alfonso López Pumarejo, aseverando que Colombia se precipitaría a una guerra civil como la de España si el gobierno liberal continuaba con las reformas emprendidas. La apología del régimen franquista de España emprendida por Laureano Gómez en el periódico El Siglo de Colombia se ve el 29 de enero de 1938, cuando Gómez expresó su beneplácito por la defensa armada, que según él, habían hecho los españoles de su país, expresando su sentimiento anticomunista y sus ideas discriminatorias respecto de los pueblos musulmanes y de la religión islámica, igualmente también da su aprobación al levantamiento sublevado encabezado por el General Franco, bajo el pretexto de restaurar la grandeza de España (Gómez, 1938, p. 260).

Gómez consideró el movimiento revolucionario franquista español como una reconquista del país, con el fin de salvarlo del terrible mal del comunismo así:

España estuvo dominada por la revolución comunista más completamente que por moros, Lenin iba a tener razón, porque la península caía, instante tras instante, en las fauces del comunismo. Entonces ocurrió uno de los momentos cruciales de la historia humana. El paladín que se creyera exánime..., se incorporó, por los causes extintos de la energía española volvió a correr sangre impetuosa; sobre el suelo que parecía maldito para la eternidad rea- pareció después de tantos años y lustros de vergüenza, la purificadora llama del heroísmo... El milagro, en que ya no se creía hizo su aparición un ejército transportado por los aires, por primera vez en la historia del mundo, empezaba ahora, por el contrario, extremo, la faena prodigiosa de la reconquista... El corriente arrollador del torrente revolucionario estaba detenido. "Bendecimos a Dios por que nos permitió presenciar esta época de transformación imprevista y por qué sintetizando día a día sentimos al conocer al soberbio, indomado empuje de los que dieron un grito que arranca de los más férvidos entusiasmos: ¡arriba España, católica e imperial!

Después de la segunda guerra mundial y con la caída definitiva de la Republica Liberal en 1945, se inició en Colombia una severa campaña anticomunista dirigida por el partido conservador, quien había ganado la presidencia de la Republica en las elecciones de 1946. Esto prueba la fórmula siempre efectiva del fascismo, de infundir temor en el pueblo ante un enemigo pocas veces digno de temer, para así lograr una unión del pueblo alrededor de sus ideales políticos, tal y como ocurrió con el temor al comunismo infundado por el partido conservador apoyado en todo momento por la jerarquía eclesiástica.

La presencia del franquismo en Colombia se ve reflejada en la política de opresión implementada por el partido conservador y la iglesia católica; opresión que provocó la derogación de las políticas inspiradas en la II República española como lo fueron la libertad de cultos, de opinión, asociación y la laicidad del Estado, tal y como se vivió en España con la victoria de las tropas sublevadas del General Franco.

A diferencia de España, en Colombia los medios que finalmente triunfaron no fueron los mismos que en España, porque los dos golpes de estado efectuados en contra del gobierno de Alfonso 
López Pumarejo fueron frustrados; pese a todo ello, la República Liberal llego a su fin con el presidente López Pumarejo, quien no pudo terminar su segundo período de gobierno para el que había sido democráticamente elegido. Esto se debió en gran medida a los implacables ataques de Laureano Gómez.

Esta circunstancia desencadenó la renuncia del presidente López Pumarejo, quien fue remplazado por Alberto Lleras, un liberal de tendencias marcadamente conservadoras, cuya misión fue retrotraer todos los avances realizados por la República Liberal. Con Alberto Lleras se inició la represión de los movimientos sociales y del sindicalismo en Colombia en el año de 1945. Luego de la II Guerra Mundial las políticas fascistas colombianas encontraron base en el discurso anticomunista, propugnado por Estados Unidos, el cual sirvió de base para la mayoría de los gobiernos conservadores entre 1949 y 1958 (Calle, 2009).

Con el fin de la presidencia del Político Liberal Alfonso López Pumarejo le siguieron una serie de Gobiernos de miembros del Partido Conservador imponiendo unas políticas propias del fascismo, estos gobiernos fueron de Mariano Ospina Pérez y Laureano Gómez, los que se ocultaron bajo el manto de la democracia, ya que el partido conservador al que ellos pertenecían ganó las elecciones de 1946, para imponer un régimen de terror por medio de la implementación de políticas claramente contrarias a la democracia (Calle, 2009).

Ante esta situación surgió un líder del Partido Liberal llamado Jorge Eliecer Gaitán, quien se distinguía de los políticos de esa época por su carisma político que lo mezclaba con sus estudios en derecho, a pesar de haberse ganado el cariño del pueblo este líder fue asesinado, lo que aseguró el inminente ascenso del candidato conservador Mariano Ospina Pérez como próximo presidente de la Republica de Colombia.
El asesinato de Jorge Eliecer Gaitán el 9 de abril de 1948 provocó una reacción desenfrenada del pueblo reclamando justicia, lo que desencadenó una revuelta popular en todo el país, en especial en Bogotá. Esta revuelta se conoció como "El Bogotazo", la cual fue sofocada de manera violenta por parte del gobierno conservador a través del despliegue del ejército. Este fue el inicio de la revuelta armada de los miembros del partido liberal, lo que poco a poco fue desarrollando un enfrentamiento armado entre los partidos conservadores y liberales.

Mariano Ospina Pérez candidato del Partido Conservador inició su gobierno con una promesa de unidad y de reconciliación entre ambos partidos, lo que se reflejó en sus inicios al constituir un gabinete como él lo denominó de "unidad nacional", en el cual había ministros de gobierno del Partido Liberal, pero progresivamente este gobierno aparentemente democrático inició una política de represión en contra de los movimientos comunistas, apoyado por la propaganda estadounidense. Este miedo al comunismo fue masificado con la finalidad de infundir temor en la población civil, ya que el gobierno confundía las protestas de trabajadores con movimientos de ideología comunista. Protestas que se originaron en el deterioro de las condiciones de trabajo y la lucha por unas condiciones laborales dignas (Calle, 2009).

Otra causa del surgimiento de la Violencia en Colombia fue el plan concebido por Laureano Gómez, programa denominado "Conservatización de la República”, el cual consistía en la segregación y desplazamiento progresivo de los miembros del partido liberal de los órganos nacionales, como departamentales y Municipales, y remplazarlos por miembros del partido conservador. La política de conservatización alcanzó su mayor expresión en el cambio de las fuerzas de la Policía, ya que se reclutó en Boyacá grupos de campesinos afines a la ideología conservadora y católica denominados quienes tomaron el nombre de "chulavitas", nombre dado por el pueblo del cual eran originarios, 
que cometieron grandes actos de violencia en contra de la población liberal (Aguilera y Vega, 1998).

Esta violencia se acrecentó en 1949, cuando el presidente Mariano Ospina declaró fuera de la ley a los habitantes liberales declarándolos bandidos y criminales, empezando así un exterminio sistemático sobre esta población. A esta dictadura democrática le sucedieron otras dictaduras civiles como la de Laureano Gómez y Roberto Urdaneta (Calle, 2009). Con el fin de defenderse los ciudadanos afines a alguno de los dos partidos empezaron a fundar o crear movimiento armados centrados en la autodefensa, por un lado, se encontraban las fuerzas del Partido Conservador la Policía (chulavita) y los pájaros (asesinos pagos) y del lado del Partido Liberal u otros opositores se encontraban las guerrillas liberales y las autodefensas comunistas. Estos grupos desencadenaron actos de extrema violencia como masacres, actos violentos con sevicia, crímenes sexuales, despojos de tierras y bienes muebles y torturas masivas (Uribe, 2004).

Solo hasta cuando esta violencia ya estaba en su máxima expresión de degradación y barbarie, las elites del partido conservador más moderadas optaron por apoyar una salida a la violencia, y es así como se propina el golpe de Estado al presidente Laureano Gómez, y así apoyando el ascenso al poder del General Gusta Rojas pinilla en 1953, el cual tenía por único objetivo detener el desangro de la nación. El perdido de la Presidencia del General Rojas pinilla se extendió entre 1953-1957. Con el objetivo de iniciar la pacificación del País el gobierno militar del General Rojas Pinilla concedió amnistías a los guerrilleros liberales y a las autodefensas campesinas, de las cuales las primeras las aceptaron y las segundas no, entre las que rechazaron el ofrecimiento del gobierno se encontraban las autodefensas campesinas del Sumapaz y el oriente del Tolima, estas eran dirigidas por el partido comunista. Frente a este rechazo el Gobierno militar inició su represión a la fuerza, lo que a la larga terminó por acelerar su transformación a guerrillas revolucionarias (Leongomez, 1991).
De esta manera se ve que los orígenes de la violencia en Colombia se encuentran marcadas por la influencia del Franquismo, sus ideales y políticas de represión. Ideales que fueron enmascarados bajo una apariencia de democracia, cuando en verdad lo que se presentaba era una dictadura democrática. Es así como se ve el vínculo entre España y Colombia, con la aplicación de políticas propias del Fascismo español. La principal diferencia entre estos países, consistía que en Colombia el régimen político se basó en el predominio de dos partidos políticos casi dinásticos, amparados en una constitución y un Estado con una marcada influencia eclesiástica como en España, circunstancia que dio origen a los eventos ocurridos posteriormente. Por este motivo, el franquismo colombiano tuvo su positivización normativa con el plebiscito de 1957, la cual volvió a dejar incólume la Constitución de 1886, retornando de esta manera al sistema iusnaturalista anterior y dejando atrás las políticas reformistas de los años treinta adoptadas por la República Liberal. A partir de este momento se dio la represión de movimientos sociales o de izquierda que se consideraban amenazas al Estado propiciando la lucha bipartidista, situación que se desarrollaría y tomaría diferentes matices hasta desembocar en el conflicto interno que atraviesa Colombia hasta el día de hoy.

\section{Conclusiones}

En el presente artículo se logró identificar que uno de los orígenes, no el único de la violencia bipartidista en Colombia, fue la ideología fascista española de los años 30; esta es una perspectiva completamente novedosa, al establecer una relación causal entre los orígenes de la violencia bipartidista, con el modelo político español abarcando desde la época colonial hasta los años $30 \mathrm{y}$ 40 años en los que se desarrolló el fascismo español, el cual encontró un espacio ideal dentro de la sociedad colombiana de esta época.

La aceptación de esta ideología no fue fortuita, sino que se debió a los rasgos comunes que 
compartía España con Colombia, aspectos como la religión, lengua, cultura e idiosincrasia, estas similitudes fueron fundamentales para la incorporación de los ideales fascistas dentro de la política y modelo colombiano.

Igualmente se logró determinar que los ideales franquistas en Colombia, no se presentaron propiamente como franquismo, pero sí se presentaron tácitamente, debido a que los ideales y políticas reflejaban las características propias del fascismo español. La Principal diferencia entre las políticas fascistas en Colombia y en España, fue que en Colombia estas políticas no fueron impulsadas por una figura de dictador o se presentó un culto a la persona; en cambio lo que se presentó una hegemonía partidaria o centradas en un partido político, lo que en un primer momento tuvieran una apariencia de democracia en verdad era una dictadura democrática, a pesar que este concepto fuera contradictorio no lo seria completamente, debido a que lo que existió fue la imposibilidad de elección de un gobernante que no fuera miembro del Partido Conservador, lo que significa que sin importar el nombre del Presidente que ocupara el puesto las políticas represivas continuaban sin alteración. Hecho propio de una dictadura, pero no encabezada en una persona, pero sí en un partido Político.

Durante estos periodos presidenciales presididos por gobernantes conservadores se impidió la participación de todo aquel considerado comunista o que representaba una amenaza real a los estamentos políticos y sociales que apoyaban al partido gobernante. Para comprender esta figura particular fue necesario conocer los antecedentes de la política colombiana, lo que significó también tratar los orígenes de la violencia en Colombia. Remitiéndose desde la colonia y su evolución a lo largo de la historia, el nacimiento de diferentes movimientos que propugnaban por la defensa de la Iglesia católica y el restablecimiento de las costumbres, en donde una élite social poseía el poder sin ningún tipo de participación de las demás clases sociales asegurando la continuidad del status quo, ideología propia del fascismo español.

A pesar que el fascismo español y el colombiano tuvieron orígenes distintos, durante el inicio de la dictadura del general Franco se presentó cierta simpatía entre los gobiernos colombianos y español encontrando en este último su modelo a seguir, esta característica se aprecia en las políticas de supresión de opositores y la persecución de los partidos políticos diferentes al del régimen y la primacía de las creencias católico cristianas.

En Colombia se presentó oficialmente una lucha bipartidista entre el partido conservador y el partido liberal generando una guerra civil, aunque esta no fue reconocida como tal por el gobierno conservador. Esta lucha se originó por la represión y en la derogación por parte del gobierno conservador de todas las políticas implementadas por el partido liberal, el cual tenían ideales propios de revolución francesa, presentándose una situación muy similar a la vivida en España durante la caída de la Segunda República.

Finalmente la violencia bipartidista llegó a su fin, pero no por medio de un vencedor de alguno de los bandos en disputa sino por medio de un golpe de estado propiciado por el General Gustavo Rojas Pinilla, el cuál fue propulsado por la voluntad popular para poner fin al derramamiento de sangre, una vez logrado un acuerdo entre los partidos políticos enfrentados por medio de un acuerdo que fue denominado "frente nacional", un acuerdo de alternación del poder entre los dos partidos políticos por 16 años, acuerdo completamente excluyente de otros partidos políticos; este acuerdo no fue la solución completa a la violencia por que varios movimientos surgidos durante la violencia partidista, no fueron desmontados y por el contrario continuaron existiendo y cambiando hasta transformarse en los actores violentos que se presentarían en la violencia actual en Colombia. 
Actualmente y de modo alentador los partidos políticos con sus ideologías, son más tolerantes, no solo socialmente sino dentro de los espacios políticos concertados. El respeto y la tolerancia son los pilares fundamentales de la paz.

\section{Referencias}

Aguilera P. y Vega Cantor, R. (1998). Ideal democratico y revuelta popular bosquejo historico de la mentalidad politica popular en Colombia, 1781- 1948. Bogotá: Universidad Nacional de Colombia.

Calle, M. L. (2009). Las dictaduras en Colombia y su sello Franquista. En F. Fernandez- Crehuet López, Derecho. memoria historica y dictaduras (págs. 413-447).

Castro, B. (1990). Caridad y beneficiencia en Cali 1848- 1898. Boletin cultural y bibliografico Vol. XXVII No 22. Bogotá.

Colmenares, G. (1989). Las convenciones contral acultura. Bogotá: Tercer Mundo.

Cordoba, E. (1967). La independencia de Haiti y su influencia en Hispanoamerica. Caracas: Instituto de Geografia e historia.

de Cuervo, J. R. (1946). Noticas de su epoca. Bogotá: Biblioteca popular de cultura colombiana.

Delgado, L. (1988). Diplomacia franquista y politica cultural hacia iberoamérica 1939-1953. Madrid: Consejo Superior de Investigaciones Cientificas.

Gómez, L. (1938). Decandencia y grandeza de España. Revista Colombiana Vol IX N. 105, 257-262.

Leongomez, E. (1991). Las Farc (1949-1966). De la autodefensa a la combinacion de todas las formas de lucha. Bogotá: Tercer mundo.

López, D. (2004). Teoria impura del derecho. La Transformacion de la cultura juridica Latinoamericana. Bogotá: Legis.

López, A. y Restrepo, C. (1986). El presidencialismo excesivo. La supersticion codificada. Bogotá: Universidad Externado de Colombia.
Mercado, A. (2015). La influencia de León Duguit en la reforma social de 1936 en Colombia. Bogotá D.C: Universidad del Rosario.

Nieto, M. (1985). Informe de la Comision Investigadora de las Responsabilidades Politicas . Bogotá: Ministerio de Guerra.

Ocampo, J. (1985). Colombia y la economia mundial 1830-1910. Revista de Historia Economica, 552- 556.

Ortiz, V. (1972). Historia de la revolucion del 17 de abril de 1854. Bogotá: Banco Popular.

Periódico el Día. (23 de Enero de 1850). Bogotá, Colombia.

Periódico el Día. (2 de Enero de 1850). El ascenso del liberalismo. Bogotá, Colombia.

Posada Eduardo, y Pedro, I. M. (1910). Relaciones de Mando. Memorias presentadas por los gobertnantes del Nuevo Reino de Granada. Bogotá: Imprenta Nacional.

Raimundo, A. (1782). Premios de la Obedencia: castigo de la inobediencia. Santa fe de Bgotá.

Tirado, A. (1981). Aspectos Politicos del Primer Gobierno de Alfonso Lopez Pumarejo 19341938. Bogotá: Instituto Colombiano de Cultura.

Tovar, H. (1996). La lenta ruptura con el pasado colonial (1810-1850). En J. A. Ocampo, Historia economica de Colombia. Bogotá: Banco de la Republica.

Uribe, J. (1986). Nuñez y Caro 1886. Bogotá: Banco de la Republica.

Uribe, M. (2004). Antropologia de la inhumanidad: Un ensayo interpretativo sobre el terror en Colombia. Bogotá: Norma.

Urrego, M. (1990). La creacion de un orden teocratico durante la Regeneración, tesis de grado Magister en Historia. Bogotá: Universidad Nacional de Colombia.

Vilar, P. (1982). Hidalgos, amotinados y guerrilleros. Barcelona: Critica.

Viñas , D. (1977). Que es el Fascismo en Litinoamerica. Bogotá: La gaya ciencia. 